Michels, Georg B. "Ready to Secede to the Ottoman Empire: Habsburg Hungary after the Vasvár Peace Treaty (1664-1674).” AHEA: E-journal of the American Hungarian Educators Association, Volume 5 (2012):

http://ahea.net/e-journal/volume-5-201

\title{
Ready to Secede to the Ottoman Empire: Habsburg Hungary after the Vasvár Peace Treaty (1664-1674) ${ }^{1}$
}

\section{Georg B. Michels, University of California, Riverside}

\begin{abstract}
In the period following the 1664 Vásvár Peace Treaty, which ended four years of warfare between the Ottoman and Habsburg Empires, large segments of the Hungarian noble elite seriously considered switching their allegiance from Vienna to Istanbul. This essay explores some of the reasons for this dramatic but little studied chapter in Hungarian history. At the center of the analysis are the secret instructions to an emissary who was to negotiate with Grand Vezir Ahmed Köpülü the conditions for Royal Hungary's secession to the Ottomans. This article examines the historical circumstances under which these instructions originated and argues that the initiative came primarily from Hungarian Protestant nobles who sought the sultan's protection to guarantee the survival of their religion which had come under threat by a brutal Habsburg-sponsored Counter-Reformation campaign. The evidence presented here sheds light on the emergence of close personal relations between Hungarian Protestant nobles and Ottoman powerbrokers, which was a crucial precondition for the Lutheran magnate Imre Thököly's success in gaining control over large parts of Habsburg Hungary with Ottoman support during the early 1680 s.
\end{abstract}

\section{Keywords:}

Biography: Georg B. Michels is Professor of History at the University of California, Riverside and is currently working on a book about the impact of the Habsburg Counter-Reformation on late seventeenth-century Hungarian society. His recent articles include "The 1672 Kuruc Uprising: A National or Religious Revolt?” Hungarian Studies Review, Vol. XXXIX, Nos. 1-2 (2012): 1-20 and a forthcoming study in Történelmi Szemle (published by the Institute of History, Hungarian Academy of Sciences) critically reexamining the expulsion of the Protestant clergy from Hungary during the early 1670s. Michels' interest in Hungary and the early modern Habsburg Empire emerged from his studies on religion, society, and revolt in early modern Russia and the discovery of significant similarities between Russian and Hungarian popular resistance against a centralizing imperial power. Trained as a Russian historian and Slavic linguist at the University of Göttingen (Germany), UCLA, and Harvard (Ph.D. 1991) he has written At War with the Church: Religion and Dissent in Seventeenth Century Russia (Stanford, 1999) and co-edited Russia's Dissident Old Believers (1650-1950) (Minneapolis, 2009).

\footnotetext{
${ }^{1}$ The original version of this article was presented at the $36^{\text {th }}$ Annual Conference of the American Hungarian Educators Association at John Carroll University, Cleveland, Ohio (April 14-17, 2011). I thank my panel chair Steven B. Várdy for his thoughtful comments.
} 

(1664-1674).” AHEA: E-journal of the American Hungarian Educators Association, Volume 5 (2012): http://ahea.net/e-journal/volume-5-201

In April 1671 the magnates Ferenc Frangepán, Péter Zrinyi, and Ferenc Nádasdy were executed in Vienna for planning the secession of Habsburg Hungary to the Ottoman Empire. These well-known and well-documented executions culminated the so-called Ferenc Wesselényi Conspiracy. According to Gyula Pauler's seminal analysis of 1876, the primary motivation of the conspiracy originated in the outrage of the Hungarian nobility about the conclusion of the Vasvár Peace Treaty (Friede von Eisenburg) in August 1664. The treaty, which ended four years of warfare between the Ottoman and Habsburg empires, was signed by the Habsburg court without knowledge of the Hungarian elite ten days after the achievement of a major military victory over the Ottomans on August 1, 1664 at Szentgotthárd (St. Gotthard-Mogersdorf) (Pauler 1876, 1: 3 81; Bene 1997).

The Vasvár Peace Treaty has been the subject of numerous studies by Hungarian historians. According to Gyula Pauler, from whom the standard historiography has derived, the Habsburg court refused to pursue the defeated Ottoman troops and missed a unique opportunity to chase the Ottomans out of Hungary once and for all. In short, Pauler argued that the liberation of Ottoman-occupied Hungary seemed indefinitely postponed and, feeling betrayed by the Habsburgs, the Hungarian political elite decided to join the Ottoman side (Pauler 1876, 1: 46-47, 51-52). Focusing on the treaty's military and diplomatic prehistory, Géza Perjés and Endre Marosi confirmed Pauler's finding that the treaty was not necessary from a military perspective because it followed a resounding victory. They argued that the Habsburg court had rushed into peace because it needed a free hand to address growing tensions with France over the Spanish Netherlands (Marosi 1971; Marosi 1983, 135; Perjés 1964). ${ }^{2}$ Ágnes R. Várkonyi and László Benczédi further detailed the sense of betrayal among Hungarian nobles who had wanted to continue the war against the Ottomans. As Benczédi put it, the conclusion of the treaty "was an explosive political event" that generated "national indignation of an elementary force" (elemi erejü orszagos felháborodás). (Benczédi 1980,11). Várkonyi went as far as to state that the treaty was against the law of history: the Habsburg court should have understood that "the expulsion of the Turk (sic) [from Hungary] was a legitimate postulate (törvényszerü követelmény) of historical development." (Várkonyi 1978, 221; Várkonyi 2002, 441, 444). Similar interpretations are found in standard English-language histories of Hungary. For example, the late István György Tóth observed that the Vasvár Treaty "left Hungarian society in a state of shock. The magnates and nobles could not resign themselves to the expulsion of the Turks from Hungary being deferred to an uncertain time in the future." (Tóth 2005, 222; Péter 1994, 115).

\footnotetext{
${ }^{2}$ Hungarian scholarship on the Vasvár Treaty has been challenged by the Austrian historian Georg Wagner who argued based on evidence from the Haus-, Hof-, und Staatsarchiv (=HHStA), Vienna that the Habsburg army and its allies were totally exhausted and that the Ottomans had not really been defeated but were regrouping for a counterattack (Wagner 1964, 442-458).
} 
Page 3 of 11

Michels, Georg B. "Ready to Secede to the Ottoman Empire: Habsburg Hungary after the Vasvár Peace Treaty (1664-1674).” AHEA: E-journal of the American Hungarian Educators Association, Volume 5 (2012):

http://ahea.net/e-journal/volume-5-201

I agree with Pauler, Benczédi, R.Várkonyi and Tóth that the Vasvár Peace Treaty had a devastating effect on the morale of the Hungarian elite. There can be no doubt about their disillusionment with the Habsburg court and the role this disillusionment played in convincing many Hungarian nobles to join the Ottoman side. However, I believe there were other important factors and precedents in addition to the Vasvár Peace Treaty that motivated Hungarian nobles' behavior. To elucidate my thinking, I will focus on one fascinating historical document that was discovered by Gyula Pauler in the Hungarian National Archives but has not yet received a careful historical analysis. I believe this document provides an important key to understanding why so many members of the Hungarian elite were willing to secede from the Habsburg to the Ottoman Empire. Signed by Count Ferenc Wesselényi, the Palatine of Royal Hungary, the document is dated August 27, 1666, almost exactly two years after the signing of the Vasvár Peace Treaty. It contains detailed instructions to an emissary who was to negotiate the secession of all of Royal Hungary to the Ottoman Empire. It bears the title "Instruction according to which the emissary is to proceed at the Porta" (Instructio, mely szerént kell procedálni az portán levö követnek) (Deák 1883, 227-232).

The Instructio has survived in the archive of Mihály Teleki, one of Transylvania's principal Calvinist leaders, in a collection of letters by Hungarian Protestant exiles who fled to Transylvania and Turkish-held territory after the Habsburg court's discovery of the Wesselényi Conspiracy in May 1670 (Gergely 1908-1912, Vol. 5). Farkas Deák published the text in 1883. The Instructio consists of a preamble and three distinct parts. The preamble outlines very carefully how the emissary was to make contact with Grand Vezir Ahmed Köprülü. It also distinguishes between those who could be trusted and those who should be avoided. Among those to be avoided, for example, was the chief Hungarian translator at the Istanbul court whom the author considered to be a Habsburg spy. The first part of the Instructio explains the reasons for the top-secret diplomatic initiative. The second part delineates the Hungarian nobility's conditions for seceding from the Habsburg Empire. And the third part defines the parameters within which the sultan's authority would be recognized by Hungarians.

The Instructio as a whole describes the castastrophe that had befallen Royal Hungary as a result of the Vasvár Peace Treaty. It maintains that the treaty had not actually created peace because Turkish troops continued to operate within the territory of Royal Hungary. Conquests of Hungarian territory made during the 1663 and 1664 Ottoman invasions had not been returned and Ottoman garrisons were now stationed in the heartlands of Royal Hungary. As a result, the over one-hundred-year-old border defense system had collapsed and "the part of the [Hungarian] state that was not under [Ottoman] rule ha[d] become very small and thin" (az országnak hódolatlan része igen kicsiny és sóvany). In addition, tax revenues had greatly declined because Ottoman officials and troops were collecting taxes from Hungarian nobles' estates. The worst Ottoman officials were the so-called sipahis, Turkish calvary men, who "were every day extracting taxes and services from places under Turkish authority (hódolt helyek) and many [of these] places have fallen therefore into utter devastation (utolsó pusztulásra juttotak)" (Deák $1883,229)$.

In the Instructio, Wesselényi appealed to Grand Vezir Ahmed Köprülü, the de facto ruler 

(1664-1674)." AHEA: E-journal of the American Hungarian Educators Association, Volume 5 (2012): http://ahea.net/e-journal/volume-5-201

of the Ottoman Empire, to intercede on Hungary's behalf with the sultan. If the sultan agreed to return recently conquered territories and establish a stable border, Hungarian nobles would be willing to become his subjects. The only stipulated condition was that the sultan recognize the age-old rights of the Hungarian nobility in a written charter (athname). Among these rights were: freedom of election, participation in diet meetings, control over military affairs, diplomatic autonomy, the right to engage in commerce, and the right to own fortresses. Once these rights had been guaranteed in writing, Hungarian nobles would view the sultan as their patron (patronus) and protector (oltalmazó). They promised to "keep a sacred peace (szent békésseget) with the Turk and with all peoples and states...under the Turkish emperor's wing (török császár szárnya alatt) as long as the Turk keeps peace with the Hungarian and all those who live under the Hungarian Crown." As a token of their submission, the Hungarian nobles committed to sending a yearly sum of money — a present (ajándék) as the Instructio phrased it — to Istanbul, adding that the farther Ottoman troops withdrew from the Hungarian border, the larger the amount of the money. The emissary was to make sure that the sultan's charter would avoid the term "tribute" (Arra is vigyázzon, hogy ezt ajándek pénznek és nem adónak irják az athnaméba). Such a tribute was paid by Transylvania, Wallachia, and other Ottoman vassal states. Were the Hungarian nobles under the illusion that they could avoid long-term integration into the "sultan's patrimony"? (Deák 1883, 231; Panaite 2000, 458-460).

The Instructio raises many questions. What prompted the writing of this document? Why did Ferenc Wesselényi, formerly an outspoken opponent of the Ottomans, appeal to the Grand Vezir for help? For example, when Prince Mihály Apafi, the Ottoman appointed ruler of Transylvania, had called on Wesselényi in October 1663 to switch his allegiance from the Habsburg to the Ottoman court Wesselényi had written back angrily. Citing the Gospel of St. Matthew he had denounced Apafi's close alliance with the Ottomans as a dangerous precedent and illusion: the Ottomans are only "raging wolves who come to you in sheep's closing." Wesselényi also had previously_ in another letter to Prince Apafi dated May 29, 1664 — spoken in glowing terms about his great hopes for a successful military campaign that would once and for all expel the Ottomans from Hungary (Papp 2003, 638; Várkonyi 2002, 441).

Two important answers to these questions are suggested by the text itself. First, one must consider the catastrophic disintegration of the Hungarian border defense system after the Vasvár Peace Treaty. According to contemporary observers, the Ottomans had essentially cut Royal Hungary into two parts with a military corridor that stretched from Érsekújvar (Neuhäusel, Nowé Zámky) — formerly a crucial Habsburg border frontier castle and now the center of Turkish power in Royal Hungary - all the way to the Moravian border. Not surprisingly, Ottoman troops were operating with impunity in Habsburg Hungary's interior. The Vienna court appears to have stood by and watched as Hungarian magnates desperately gathered militias to defend their estates. Second, Hungarian magnates and nobles were in great danger of losing control over their tax revenues and serfs. Meetings in county assemblies denounced the aggressive behavior of Ottoman tax collectors and particularly the sipahis who were seizing noble lands and forcing peasants to recognize their authority. Again, the Habsburg court apparently did not do anything to stop this process. Under the circumstances it is not surprising that Hungarian elites chose to 
Page 5 of 11

Michels, Georg B. "Ready to Secede to the Ottoman Empire: Habsburg Hungary after the Vasvár Peace Treaty (1664-1674).” AHEA: E-journal of the American Hungarian Educators Association, Volume 5 (2012):

http://ahea.net/e-journal/volume-5-201

approach the Ottoman side in order to avoid the total destruction of their livelihood. These grim realities, which were noted by László Benczédi shortly before his death but which continue to be ignored by modern scholarship, have to be studied in future research (Benczédi 1985, 27-28).

Here I want to focus on a third answer, which takes into account the threatened state of Protestant religion in Habsburg Hungary. Although the text does not explicitly refer to religion, its importance is suggested by other evidence. Most significantly, while the Instructio carries only Wesselényi's signature it is clear that it emerged as a result of lengthy negotiations between Wesselényi and Hungary's leading Protestant lords. These negotiations are reported in letters by participants as well as later Habsburg investigations. Wesselényi hosted these lords at Murány Castle, his home in Gömör county, on August 23, 1666 for a meeting. It is unclear who initiated this meeting, but the Instructio summarized the position agreed upon by the meeting's participants by its conclusion four days later (Pauler 1876, 1: 98-102; Jankovics 1987, 138-153).

Unfortunately, we know almost nothing about the actual negotiations, but later testimonies by participants suggest that the four-day meeting was dominated by Hungary's most important Protestant leaders. Of the twenty-one attendees whose names can be reconstructed only five were Catholics: they included Ferenc Wesselényi and the magnate Ferenc Csáky, commander-in-chief (fökapitány) of Hungarian troops in the Upper Hungarian border defense system. There were also three other less powerful Catholic nobles in attendance. But the other known participants were all Protestant. Foremost among them were Mátyás Szuhay, county magistrate (táblabiró) of Abauj county, a determined Calvinist opponent of the Catholic church who had been the principal spokesperson of the Protestant party at the 1662 National Diet in Pozsony, and Pál Szepessy, deputy county high sheriff (alispán) of Borsod county, who had been chosen by Upper Hungary's thirteen largely Calvinist counties to represent their interests in Vienna. There were several outspoken defenders of the Calvinist faith such as László Fay and Ferenc Ispán of Abaúj county, and Gábor Kende from Szatmár county. Hungary’s most important Lutheran magnate, István Thököly, although not present himself, was represented by several clients, among them Menyhért and András Keczer, two fervent anti-Catholics who dominated the political affairs of Sáros county, and István Vitnyédi, the well-known advocate of Protestant freedoms from Lower Hungary (Pauler 1876, 1: 101-102; Jankovics 1987, 147, 153, 616; Zsilinsky 1893, 137, 189-190, 192, 235, 247; Nagy 1999). ${ }^{3}$

Why did all of these Protestant nobles gather at Palatine Wesselényi's castle to discuss secession to the Ottoman Empire? This is an interesting question because these Protestant nobles had previously denounced Wesselényi at several national diet meetings for failing to protect their religion. At the national diets of 1659 and 1662, for example, they had confronted him with long

\footnotetext{
${ }^{3}$ Additional data are located in HHStA, Ungarische Akten, Spezialia, Fasc. 294, Konv. C, fols. 1-14, Interrogation of András Nagy Figedi (a Calvinist participant in the meeting from Abaúj county). András Keczer had represented the Lutheran nobility of Sáros county at the 1659 National Diet; he was tried in April 1671 for having given public speeches calling for the secession of Hungary to the Ottomans. Cf. HHStA, Ungarische Akten, Spezialia, Fasc. 293, Konv. C, fols. 1-31, Processus causae Andreae Keczer.
} 
Page 6 of 11 Michels, Georg B. "Ready to Secede to the Ottoman Empire: Habsburg Hungary after the Vasvár Peace Treaty (1664-1674).” AHEA: E-journal of the American Hungarian Educators Association, Volume 5 (2012): http://ahea.net/e-journal/volume-5-201

lists of grievances about the confiscation of Protestant churches and the expulsion of Protestant ministers, and accused Wesselényi of protecting the Catholic clergy and magnates responsible for these violent acts. Wesselényi had failed to either speak out or take action against Archbishop György Szelepcsényi, the Hungarian chancellor, whose "men...have seized churches by force (eröszakkal efoglaltak) and coerced the people into the Catholic faith resorting to [all kinds] of torments." Wesselényi had also stood by silently when Catholic magnates such as Ferenc Nádasdy and Pál Eszterhazy resorted to similar measures. He simply refused to intercede on the Protestants' behalf with Emperor Leopold I and even warned that they should not overestimate their power. As he put it, the legendary princes of Transylvania, István Bocskay and Gábor Bethlen, were long dead and the current Transylvanian leader was a Turkish client. If they would not let go of their complaints he and the emperor would consider them rebels. Also, Wesselényi told the Protestant delegates that their religious grievances were much less important than solving the Turkish Question (Türkenfrage) (Zsilinszky 1893, 222, 224-225; Obál 1910, 108, 141).

It was precisely because of Wesselényi's failure to address their religious grievances that a significant number of Protestant leaders, among them the Calvinists who participated in the meeting at Murány Castle, had already considered seceding to the Ottoman side well before the Vasvár Peace Treaty. The first recorded instance of this occurred on September 30, 1662 when the Gömör county diet declared publically that its Lutheran and Calvinist nobles would not be willing to take up arms against the Ottomans. When Wesselényi begged these nobles to raise troops to stop the imminent Ottoman invasion, they responded that they had endured much from pillaging Turkish and Habsburg troops but "what hurt[s] them still deeper and more painfully than all of these [actions]" (mind ezeknél mégis majdnem jobban és fájdalmasabban sért) was the attack on their faith. The Hungarian Primate, György Lippay, had seized the tithe of their churches, with the help of the Habsburg army. And the small minority of Catholic nobles in Gömör county had started to expel Protestant pastors and seized Protestant churches, cemeteries, and schools buildings (Pauler 1876, 1: 61; Zsilinszky 1893, 232).

Similarly, in late November 1663, during a regional diet meeting in the Protestant stronghold of Eperjes, the Lutheran and Calvinist nobles of thirteen Upper Hungarian countiestogether with delegates from Upper Hungary's major towns - announced that they were ready to secede to the Ottoman Empire. They had had enough. Zsófia Báthory, the widow of György Rákóczi II, began persecuting Protestant communities on her far-flung estates after her conversion to the Catholic faith in 1661. Countless churches and schools had been deprived of the generous endowments previously granted by the historically Calvinist Rákóczi clan. And many ministers and teachers had been expelled with the help of the Habsburg troops. As some of the Eperjes delegates put it, "Allah was better than Wer da" (inkább Allah, mint Wer da), a saying that was used quite often in Protestant Upper Hungary during these years. "Wer da"German for "Who is there?"-referred to the Habsburg army which was supposed to defend Royal Hungary, but was instead lending its hand to a brutal Counter-Reformation campaign unleashed by Catholic Hungarian magnates and bishops. Upon learning about the readiness of the thirteen counties to secede to the Turks the Habsburg Emperor Leopold I had issued a 
Page 7 of 11

Michels, Georg B. "Ready to Secede to the Ottoman Empire: Habsburg Hungary after the Vasvár Peace Treaty (1664-1674).” AHEA: E-journal of the American Hungarian Educators Association, Volume 5 (2012):

http://ahea.net/e-journal/volume-5-201

manifesto with strict warnings "not to submit to the Turks under any circumstances" (das man den Türcken durchaus nicht huldigen soll). However, as long as their religious grievances were not addressed Upper Hungarian elites remained willing to turn to the Turks for help (Pauler 1876, 1: 63; Hain 1910-1913, 300, 304, 310-311, 313).

The Eperjes diet occurred at the height of the Ottoman invasion after the Turks had conquered the Habsburg fortress of Érsekújvar, which had been a lynchpin of the Hungarian border defense system in Nyitra county since the late sixteenth century. Érsekújvar was stormed on Sept. 24, 1663 after a six-week siege but other important fortresses such as Nyitra, Léva and Nógrád also fell into Ottoman hands during the same campaign. After this military disaster, the Habsburg border defense system was in shambles and a Turkish breakthrough to Pozsony and Vienna seemed imminent; in fact, Turkish troops had already cut through Hungary into Moravia (Strauß 1991, 73-77; Pálffy 2000, 58). On October 18, 1663 a Calvinist delegation led by Prince Mihály Apafi, the Ottoman puppet ruler of Transylvania, met with the triumphant Grand Vezir Ahmed Köprülü in Érsekújvar. Among the delegation were several Upper Hungarian nobles and István Czeglédi, Upper Hungary’s leading Calvinist minister. Shortly afterwards, Apafi published a proclamation that called on Hungarians to accept the sultan as their overlord. This proclamation may have provided the impetus for the announcement of Upper Hungarian Protestants that they were ready to secede to the Ottoman Empire (Papp 2003, 636; Varga 2007, 291).

Andreas Neuman, the Prussian emissary to the Vienna court, reported on October 25, 1663, that Protestant Hungarian nobles from both Upper and Lower Hungary had told him: "It is better to succumb to the Turks peacefully (in Güte). If the Emperor gains victory we will lose our freedom especially in religious affairs (Religionssachen). Under the Turk, however, [we] will maintain our [freedom]." However, Neuman believed that only Upper Hungarian Protestants were serious about secession. He noted that the Upper Hungarian estates were unwilling to join the general military mobilization against the Ottomans. In June 1663, for example, he observed that "they do not want to do anything before they are given back their confiscated churches" (Marczali 1881, 120-121, 123-126, 130).

Neuman's reports to Berlin and the above mentioned diet meetings demonstrate that proOttoman attitudes were already in existence among Protestant nobles before the Vasvár Peace Treaty. By the time Protestant leaders met with Wesselényi in August 1666, they had already initiated contacts with the Grand Vezir as well as with pashas across the border. According to János Bethlen's History of Transylvania and other contemporary sources, Upper Hungarian Protestants such as Pál Szepessy were frequent visitors at the palace of Pasha Kara Ibrahim of Eger. They freely conversed with Ibrahim in Hungarian and respected him both for his learnedness and his friendliness toward Hungary. They also had close contacts with the vezir of Buda (Bethlen 1993, 317; Jankovics 1987, 143, 145, 147, 617). Clearly, the issue of Protestant religious survival and Protestant nobles' cross-border contacts with Ottoman powerbrokers played a significant role in the prehistory of the meeting at Murány Castle although again it remains unclear how and why Protestant leaders and Wesselényi came to agree on the terms of the Instructio or why only Wesselényi's signature appears on the document. 

(1664-1674).” AHEA: E-journal of the American Hungarian Educators Association, Volume 5 (2012): http://ahea.net/e-journal/volume-5-201

The diplomatic initiative outlined in the Instructio was not successful. The emissary was unable to contact Grand Vezir Köprülü before the summer of 1667, almost a full year after the Instructio had been formulated-because Köprülü was on Crete leading the Ottoman siege of the Venetian fortress of Candia. When the meeting finally occurred, Köprülü told him that he did not have time to address matters in Hungary since he was intent on winning the war with Venice. Also, Köprülü was reluctant to break the Vasvár Peace Treaty and mobilize his troops for another campaign against Vienna. However, the Grand Vezir did hold open the possibility of a future alliance. According to the History of Transylvania he told the emissary "we hope that there will still be an opportunity for demonstrating [your] loyal services successfully" (hüséges szolgálatait eredményesen megbizonyítsa) (Bethlen 1993, 321; Gergely 1908-1912, 4: 167-170).

We don't know how Wesselényi would have responded if the Grand Vezir had accepted the Instructio. Wesselényi died from illness in March 1667, before the meeting between the emissary and the Grand Vezir had even taken place. The Catholic magnate Ferenc Nádasdy, took up the initiative after Wesselényi's death and resumed direct negotations with the Ottomans. Like Wesselényi, he relied heavily on existing ties between Lutheran and Calvinist leaders and the Ottomans. Nádasdy acknowledged this in a letter to a close associate dated June 9, 1667, expressing his fear that Protestant nobles - especially the magnate István Thököly-were keeping him in the dark about Ottoman intentions. As he put it, "they should be sincere with me, or this will not end well" (öszintéskedjenek, különben nem lesz jó vége). He was determined "not to become anyone's schoolchild...[and] did not want to be led by his nose" (senki oskolabeli deákjának nem lenni...nem akarta magát orránál fogva vezettetni) (Pauler 1876, 1: 144). ${ }^{4}$

Nádasdy most likely exaggerated the ability of Protestant nobles to manipulate events because - as Gyula Pauler demonstrated - he became the central figure of the pro-Turkish conspiracy that unfolded during the remainder of the 1660s. By 1670, when the conspiracy was discovered, Nádasdy had formed close alliances with Hungary's principal Catholic magnates Ferenc Rákóczi, Péter Zrinyi, and Ferenc Frangepán. It remains unclear to what extent Protestant and Catholic nobles cooperated during this conspiracy, or why leadership shifted to Catholic magnates. The Protestant network continued to exist after 1670 while the Catholic network dissolved after the execution of its leaders in April 1671. By the end of the 1670s, Imre Thököly had assumed leadership of the Protestant network that had its origins in the years before the Vasvár Peace Treaty. A close alliance with the Ottomans and the granting of the Sultan's athname in April 1681 and again in September 1682 were crucial preconditions for Thököly's success in gaining control over large parts of Habsburg Hungary (Varga 2007, 294-295; Papp 2003, 648-649; Szakály 1983, 64-66).

From a careful analysis of the 1666 Instructio, it is clear that the origins of the Hungarian initiative to secede from the Habsburg to the Ottoman Empire cannot be explained solely in

\footnotetext{
${ }^{4}$ See also HHStA, Ungarische Akten, Spezialia, Fasc. 292, Konv. A, Interrogation of Valentin Szenthe (Nádasdy's secretary), fols. 49-91, Delucidatio relationum mearum ad puncta interrogatoria.
} 

(1664-1674)." AHEA: E-journal of the American Hungarian Educators Association, Volume 5 (2012): http://ahea.net/e-journal/volume-5-201

terms of Hungarian nobles' discontent with the Vasvár Peace Treaty. Previous historical interpretations have not adequately addressed the dimension of religion. As I have demonstrated, Hungarian Protestant magnates and nobles were crucially involved in drafting the Instructio. These were the same nobles who had fought the Counter-Reformation and expressed willingness to cut their ties with the Vienna court already before the conclusion of the Vasvár Peace Treaty. Thus, the so-called Wesselényi Conspiracy emerged against the backdrop of a violent CounterReformation campaign — still largely unexplored by historians - that threatened the destruction of the Lutheran and Calvinist faith in large parts of Hungary (Michels 2010, 109-110). The role of Protestant religion and the overriding concern for protecting religious freedoms need to be taken into account in understanding what motivated Hungarian nobles to join the principal power of the early modern Islamic world in the late seventeenth century.

\section{Works Cited}

Benczédi, László. 1980. Rendiség, abszolutizmus és centralizáció a XVII század végi Magyarországon (1664-1685) [Feudalism, Absolutism, and Centralization at the End of the Seventeenth Century in Hungary (1664-1685)]. Budapest: Akadémiai Kiadó.

Benczédi, László. 1985. “A török orientáció a XVII. század végi Magyar politikában,” [The Turkish Orientation in Hungarian Politics at the End of the Seventeenth Century] in Péter Németh, László Iklódi and Péter Hársfalvi, eds., A török orientáció a XVII. század Magyar politikában. Tudományos emlékülés. Vaja: Nyírségi Nyomda. 21-33.

Bene, Sándor. 1997. "Hóhérok teátruma: A Wesselényi mozgalom perei és a hazai recepció kezdetei," [The Executioners Theater: The Origins of the Wesselényi Movement Trials and their National Reception] In Siralmas jajt érdemlö játék. Magyar nyelvü tudósitás a Wesselényi mozgalomról. [A Deplorable Game: Hungarian Language Reporting on the Wesselényi Movement] Ed. Emil Hargittay, Pilisczaba: Pázmány Péter Katolikus Egyetem Bölcsészettudományi Kar. 32-85.

Bethlen, János. 1993. Az Erdélyi történelem. [The History of Transylvania] Eds. József Jankovics and Judit Nyerges. Budapest: Balassi Kiadó.

Deák, Farkas. 1883. Ed. A bujdosók levéltára. A Gróf Teleki-család Maros-Vásárhelyi leveltárából [The Exiles' Archive: From the Count Teleki Family’s Maros-Vásárhelyi Archives]. Budapest: M. T. Akadémia.

Gergely, Sámuel. 1908-1912. Ed. Teleki Mihály levelezése (1670-1674). A Római Szent Birodalmi Gróf Széki Teleki család oklevéltára [Mihály Teleki’s Correspondence (16701674): The Holy Roman Empire's Count Széki Teleki Family Archives]. Commissioned by A Magyar Történelmi Társulat. Vols. 4-6. Budapest: Athenaeum.

Hain, Gáspár. 1910-1913. Szepességi vagy löcsei krónika (Zipserische oder Leütschaverische Chronik vndt Zeit-beschreibung) [The Chronicle of Szepes or Löcse (The Chronicle of Zips or Leutschau and its Times)]. Eds. Jeromos Bal, Jenő Förster, and Aurél Kauffmann. Lőcse: A Szepesmegyei Történelmi Társulat, 1910-1913. 
Page 10 of 11

Michels, Georg B. "Ready to Secede to the Ottoman Empire: Habsburg Hungary after the Vasvár Peace Treaty (1664-1674).” AHEA: E-journal of the American Hungarian Educators Association, Volume 5 (2012):

http://ahea.net/e-journal/volume-5-201

Jankovics, József, Péter Kulcsár, and Gáborné Nényei. 1987. Eds. Bethlen Miklós levelei (1657 1698) [The Letters of Miklós Bethlen, 1657-1698]. Vol. 1. Budapest: Akadémiai Kiadó.

Marczali, Henrik. 1881. Comp. "Regesták a külföldi levéltárokból a török magyar viszonyok történetéhez 1660-1664 közt." [Documents from Foreign Archives on the History of Turkish-Hungarian Relations between 1660 and 1664]. Történelmi Tár, 114-138.

Marosi, Endre. 1971. "Megjegyzék az 1664. évi hadjárat és a vasvári béke értékeléséhez" [Remarks towards an Evaluation of the 1664 Military Campaign and the Vasvár Peace]. Hadtörténelmi Közlemények, 107-128.

Marosi, Endre. 1983. "Der ungarische Abwehrkampf gegen die Türken 1352-1718. Ein historischer Überblick" [The Hungarian Rearguard Action Against the Turks, 13521718]. Abrahamovicz, Zygmunt, Vojtech Kopčan, Metin Kunt, Endre Marosi, Nenad Moačanin, Constantin Serba, Karl Teply. Eds. Die Türkenkriege in der historischen Forschung [The Turkish Wars in Historical Research] Vol. 13 of Forschungen und Beiträge zum Wiener Stadtgeschichte [Research Contributions to the Urban History of Vienna]. Ed. Felix Czeike. Wien: Franz Deuticke.

Michels, Georg B. 2010. "The Counter-Reformation and the 1672 Kuruc Revolt," in Jaroslav Miller and László Kontler, eds., Friars, Nobles and Burghers - Sermons, Images and Prints.Studies of Culture and Society in Early-Modern Europe. In Memoriam István György Tóth. Budapest-New York: Central European University Press. 107-126.

Nagy, Levente. 1999. "Néhány adat Wittnyédy István erdélyi kapcsolataihoz” [A Few Facts on István Wittnyédy’s Transylvanian Connections]. Századok, no. 6: 1217-1246.

Obál, Béla. 1910. Die Religionspolitik in Ungarn nach dem Westfälischen Frieden während der Regierung Leopolds I [Religious Politics in Hungary after the Peace of Westphalia and during the Reign of Leopold I]. Halle: Wischan \& Burkhardt, 1910.

Pálffy, Géza. 2000. “The Origins and Development of the Border Defence System Against the Ottoman Empire in Hungary (Up to the Early Eighteenth Century)". Dávid, Géza and Pál Fodor. Eds. Ottomans, Hungarians, and Habsburgs in Central Europe. The Military Confines in the Era of Ottoman Conquest. Vol. 20 of The Ottoman Empire and its Heritage. Politics, Society, and Economy. Eds. Faroqhi, Suraiya and Halil Inalcik. Leiden-Boston-Cologne: Brill. 3-71.

Panaite, Viorel. 2000. The Ottoman Law of War and Peace. The Ottoman Empire and Tribute Payers. New York: Columbia University Press.

Papp, Sándor. 2003. "Szabadság vagy járom? A török segítség kérdése a XVII. század végi magyar rendi mozgalmak idején" [Freedom or Oppression? The Question of Turkish Help at the Time of the Hungarian Feudal Movements at the End of the Seventeenth Century]. Hadtörténelmi Közlemények, 633-669.

Pauler, Gyula. 1876. Wesselényi Ferencz nádor és társainak összeesküvése [The Conspiracy of Palatine Ferencz Wesselényi and his Companions]. Vols. 1-2. Budapest: M. T. Akadémia, 1876.

Perjés, Géza. 1964. "A szentgotthárdi csata” [The Battle of Szentgotthárd]. Vasi Szemle, 321 356. 
Michels, Georg B. "Ready to Secede to the Ottoman Empire: Habsburg Hungary after the Vasvár Peace Treaty (1664-1674).” AHEA: E-journal of the American Hungarian Educators Association, Volume 5 (2012):

http://ahea.net/e-journal/volume-5-201

Péter, Katalin. 1994. "The Later Ottoman Period and Royal Hungary." Sugar, Peter F., Péter Hanák and Tibor Frank. Eds. A History of Hungary. Bloomington and Indianapolis: Indiana University Press.

Strauß, Johann. 1991. Ed. Die Chronik des Isazade. Ein Beitrag zur osmanischen Historiographie des 17. Jahrhundert [The Chronicles of Isazade: A Contribution to the Ottoman Historiography of the Seventeenth Century]. Berlin: Klaus Schwarz Verlag.

Szakály, Ferenc. 1989. “Az 1670-es évek Habsburg-ellenes mozgalmai és a hódoltsági Magyar feudalis hatalom" [The Anti-Habsburg Movements of the 1670s and Hungarian Feudal Power under Ottoman Occupation] László Benczédi. Ed. A Thököly-felkelés és kora [The Thököly Uprising and Its Times]. Budapest: Akadémiai Kiadó. 59-67.

Tóth, István György. 2005. A Concise History of Hungary. Budapest: Corvina/Osiris.

Varga, János J. 2007. “A török orientáció változatai Magyarországon. Wesselényi - Apafi Thököly 1663-1683" [The Changes in the Turkish Orientation in Hungary: Wesselényi Apafi - Thököly 1663-1683]. Történelmi Szemle, no. 2: 289-297.

Várkonyi, Ágnes R. 1978. Magyarország keresztútjain. Tanulmányok [Hungary at the Crossroads: Essays]. Budapest: Gondolat.

Várkonyi, Ágnes R. 2002. “A Wesselényi szervezkedés történetéhez 1664-1671” [Towards a History of the Wesselényi Organization]. Pál, Fodor, Géza Pálffy and István György Tóth. Eds. Tanulmányok Szakály Ferenc emlékére [Essays in Memory of Ferenc Szakály]. Budapest: MTA TKI Gazdaság- és Társadalomtörténeti kutatócsoportja. 423460.

Wagner, Georg. 1964. Das Türkenjahr 1664. Eine Europäische Bewährung. Raimond Montecuccoli, die Schlacht von St. Gotthard-Mogersdorf und der Friede von Eisenburg (Vasvár) [The Turkish Year 1664. A European Moment of Truth. Raimond Montecuccoli, the Battle of Szentgotthárd and the Vasvár Peace]. Eisenstadt: Michael R. Rötzer.

Zsilinszky, Mihály. 1983. A Magyar országgyülések vallásügyi tárgyalásai a Reformátiótól kezdve [Hungarian Parliamentary Debates on Religious Affairs from the Beginning of the Reformation]. Vol. 3 (1647-1687). Budapest: Viktor Hornyánszky. 